UDC 378.147:341.462.1(4)“1991/2004"

DOI 10.24919/2519-058X.19.233840

\begin{abstract}
Andrii SAVCHUK
Master of International Relations, post-graduate student of State Higher Educational Institution "Vasyl Stefanyk Precarpathian National University", 57 T. Shevchenko Street, Ivano-Frankivsk, Ukraine, postal code 76018 (carrrcosa@gmail.com)
\end{abstract}

ORCID: 0000-0001-5280-3647

\title{
Igor TSEPENDA
}

PhD hab. (Political Sciences), Professor, Rector of State Higher Educational Institution "Vasyl Stefanyk Precarpathian National University", 57 T. Shevchenko Street, Ivano-Frankivsk, Ukraine, postal code 76018 (rector@pnu.edu.ua)

ORCID: 0000-0003-2926-8935

Researcher ID: 3164111/igor-tsependa/

\begin{abstract}
Андрій САВЧУК
магістр міжнародних відносин, аспірант ДВНЗ "Прикарпатський наиіональний університет імені Василя Стефаника”, вул. Шевченка, 57, м. Івано-Франківськ, Україна, індекс 76018 (carrrcosa@gmail.com)
\end{abstract}

\section{Ігор ЦЕПЕНДА}

доктор політичних наук, професор, ректор ДВНЗ “Прикарпатський наиіональний університет імені Василя Стефаника”, вул. Шевченка, 57, м. Івано-Франківськ, Україна, індекс 76018 (rector@рпи.еdи.иа)

Bibliographic Description of the Article: Savchuk, A. \& Tsependa, I. (2021). Training of diplomatic staff in the Visegrad Group states (V4) (1991 - 2004): preconditions for formation. Skhidnoievropeiskyi Istorychnyi Visnyk [East European Historical Bulletin], 19, 191-203. doi: 10.24919/2519-058X.19.233840

\section{TRAINING OF DIPLOMATIC STAFF IN THE VISEGRAD GROUP STATES (V4) (1991 - 2004): PRECONDITIONS FOR FORMATION}

\footnotetext{
Abstract. The purpose of the study is to reveal the preconditions for the formation and development of diplomatic systems and training of diplomatic personnel in the Visegrad Group states (V4) in 1991 2004. The Research Methodology. The research methodology is based on the principles of historicism, objectivity, system, science, as well as the use of general scientific (analysis, synthesis, generalization) and special historical (historical and typological, historical and systemic) methods. The scientific novelty consists in the fact that for the first time in the Ukrainian and foreign science the preconditions for formation of diplomatic systems and training of diplomatic personnel in the Visegrad Group states (V4) $(1991$ - 2004) have been considered in organic unity; the groups of external and internal factors have been singled out, which influenced these processes; the peculiarities of the formation and development of diplomatic systems and training of relevant specialists in each of the Visegrad Group states (V4) have been analyzed. The Conclusions. The singled out factors that influenced the formation and development of diplomatic systems and diplomatic personnel training in the Visegrad Group states (V4)
} 
(1991 - 2004) are conditionally grouped into external ones (macro-factors: the collapse of the Soviet Union, the fall of the Berlin Wall, the collapse of the communist regime, the acquisition of independence and sovereignty by Poland, Czechoslovakia, Hungary, the organization of diplomatic services of these states, strengthening one's own image at the international level, participation of the states in international structures, international policy, EU educational initiatives, etc.) and domestic (meso- and micro-factors: the socio-political situation in the Visegrad Group states (V4), the development of the diplomatic service, the foreign policy course of the state, the official policy of Visegrad and the Bologna system, the national educational policy of each of the states, the appropriate regulatory framework, the development of higher education in each of the states, educational systems in the Soviet Union and in Ukraine, where specialists in international relations were also trained, foreign language education as a priority public policy, etc.). These groups of determinants are interconnected and form a complex system that programmed the creation of diplomatic services, the development of diplomatic education in the Visegrad Group states (V4).

Key words: the Visegrad Group states (V4), Poland, the Czech Republic, Slovakia, Hungary, diplomatic system, training of diplomatic personnel.

\title{
ПІДГОТОВКА ДИПЛОМАТИЧНИХ КАДРІВ У ДЕРЖАВАХ ВИШЕГРАДСЬКОЇ ЧЕТВІРКИ (1991 - 2004 рр.): ПЕРЕДУМОВИ СТАНОВЛЕННЯ
}

\begin{abstract}
Анотація. Мета дослідження полягає у розкритті передумов становлення та розвитку дипломатичнихсистеміпідготовкидипломатичнихкадрівудержавах Вишеградськоїчетвірки (V4) y 1991 - 2004 рр. Методологія дослідження. В основі методології дослідження лежать принципи історизму, об'єктивності, системності, науковості, а також використання загальнонаукових (аналіз, синтез, узагальнення) та спеціально-історичних (історико-типологічний, історикосистемний) методів. Наукова новизна полягає у тому, щзо вперше в украӥнські та зарубіжній научі розглянуто передумови становлення дипломатичних систем та підготовки дипломатичних кадрів у державах V4 (1991 - 2004 рр.) в органічній єдності, виокремлено групи зовнішніх та внутрішніх чинників, які впливали на ці прочеси, проаналізовано особливості становлення та розвитку дипломатичних систем та підготовки відповідних фахівиів у кожній з держав V4. Висновки. Виокремлені чинники, які впливали на формування та розвиток дипломатичних систем та підготовку дипломатичних кадрів у державах V4 (1991 - 2004 рр.), умовно згруповано в зовнішні (макрочинники: розпад Радянського Союзу, падіння Берлінської стіни, крах комуністичного режиму, набуття незалежності та суверенітету Польщею, Чехословаччиною, Угорщиною, організація дипломатичних служб циих держав, зміцнення власного іміджу на міжнародному рівні, участь держав у міжнародних структурах, міжнародна політика, освітні ініціативи СС тощсо) та внутрішні (мезо- та мікрочинники: суспільно-політична ситуаиія в державах V4, розвиток дипломатичної служби, зовнішньополітичний курс держави, офіщійна політика Вишеграду та Болонська система, національна освітня політика кожної з держав, належна нормативнозаконодавча база, розвиток вищої освіти у кожній з держав, освітні системи в Радянському Союзі і в Украӥні, де теж готувалися кадри фахівиів з міжнародних відносин, іншомовна освіта як пріоритетна державна політика тощо). Ці групи детермінант взаємопов'язані і творять складну систему, що програмувала створення дипломатичних служб, розвиток дипломатичної освіти у державах $V 4$.
\end{abstract}

Ключові слова: Вишеградська четвірка, Польщча, Чехія, Словаччина, Угорщчина, дипломатична система, підготовка дипломатичних кадрів.

The Problem Statement. In Ukraine, in the field of international relations, qualitative changes take place, which have put on the agenda the need to find the ways to modernize diplomatic services and improve the diplomatic staff training. Theoretical study of the scientific problem formulated in the title of the article revealed a number of contradictions between: the need to develop international cooperation against the background of an unstable 
socio-political and socio-economic situation and the need to improve the system of training competent diplomatic personnel who are able to perform professional duties qualitatively; challenges and needs, which the modern globalized world puts forward to specialists in international relations, and the insufficient level of professional competence of specialists in international relations; the need to study the foreign experience of training diplomatic personnel and the lack of its systematic study and generalization in the domestic educational theory and practice, etc.

Under such circumstances, it is useful and necessary for Ukraine to study the experience of creating diplomatic systems, training of diplomatic personnel in the Visegrad Group states (V4) (1991 - 2004), which ensured the successful development of the member states, their active advancement on the path of integration into the EU and NATO.

TheAnalysis of Sources and Recent Researches. At the beginning of the XXIst century in Ukraine and abroad there appeared some studies on the problems of historical formation and development of the Visegrad Group states (V4) (Moroz, 2005; Ukraine, 2010; Hotkova, 2012; Shishelina, 2014), their international activities (Kish, 2012), in particular relations with Ukraine (Serhiienko, 2012; Ukraine, 2010), the problems of political socialization of the youth of the Visegrad Group states (V4) are studied (Stelmakh, 2015) and the others. However, the experience of the Visegrad Group states (V4) in the training of diplomatic personnel has not been the subject of researches, which actualizes writing of this article.

The purpose of the article is to analyze the preconditions for the formation and development of training of diplomatic personnel in the Visegrad Group (V4) in 1991 - 2004 in terms of its topicality and prospects for use in Ukraine.

The Main Material Statement. The Visegrad Group (V4) - unification of Central European states (Poland, the Czech Republic, Slovakia, Hungary) with a rather limited institutional structure. Its formation was announced by the leaders of the three post-socialist countries Lech Walesa, Vaclav Havel, and Jozef Antala at a meeting on February 15, 1991 in the Hungarian city of Visegrad (Declaration, 1991), where a joint declaration on the desire to integrate into European structures was signed (Visegrad Group, 2004, p. 112, 114). The collapse of the Soviet Union and liberation from the communist regime motivated the leaders of these states to intensify mutual cooperation in the region in order to establish in the international arena, security and socio-economic and cultural development (The Visegrad Group, 1993).

The state-building processes and qualitative changes in the geopolitical situation of the Visegrad Group states (V4) led to complex processes of creation and development of their own national diplomatic services, which in turn actualized the need to provide them with qualified personnel. The creation of national systems for the training of diplomatic personnel in the Visegrad Group (V4) is a complex and dynamic process that has more than a quarter of a century of history, marked by stages of evolutionary change that continue to this day. This was due to the openness of this system, which responds quickly to the nature and changes in both domestic policy and its foreign policy, the international situation, the challenges of globalization, and other factors. We define three levels of determinants of the process of training diplomatic personnel in the Visegrad Group states (V4) of the period under analysis. They are characterized by a number of stable and variable macro-, meso- and micro-factors, which together reflect the diversity of foreign policy, socio-political, socio-economic, cultural and educational life and emphasize the impact of these spheres of public life on the development and modernization process of the system of training of diplomatic personnel in the Visegrad Group states (V4), and hence the formation of diplomatic systems. 
Macro-factors include global, well-established determinants, which under any changes and challenges determined the main vectors and strategy of training systems formation in the field of international relations. The main goal is to train personnel capable of ensuring the national interests and security of the Visegrad Group member states by maintaining peaceful and mutually beneficial cooperation with members of the international community in accordance with generally accepted principles and norms of international law; implementation of a foreign policy course aimed at the development of political, economic, humanitarian, scientific, and other relations with other states, international organizations; protection of the rights and interests of citizens and legal entities abroad; promoting the stability of the international situation of each state, raising its international prestige, carrying out other tasks in accordance with current legislation, etc.

In the aspect of foreign policy of the states the following macro-factor had a significant influence on the system formation of diplomatic personnel training of the Visegrad Group states (V4), as cooperation with the world and European structures, organizations and institutions, first of all the UNO and its structures (UNESCO, IAEA, WHO, UNICEF), European Union, the NATO, Organization for Security and Co-operation in Europe (OSCE), International Bank for Reconstruction and Development (IBRD), European Bank for Reconstruction and Development (EBRD), Central European Free Trade Association (CEFTA), etc. It is important to note that as early as in 1951 (the year of signing of the Treaty of Paris) there was a need for a coordinated external representation of the European Community (EU). In 1954 the European Commission's External Relations Service was established. Conventionally, the history of the development of the EU diplomatic structures can be divided into two major stages: the first covers the 1950s and the 1990s, when the EU carried out economic diplomacy mostly, as there was no other type of diplomatic activity here; the second stage, which began in 1997, continues to this day, associated with the Treaty of Amsterdam and the crystallization of European institutions and structures. At the beginning of the first period, a non-profit semi-autonomous institution was created - European Cooperation Agency (EEA), which had an impact on the formation of pan-European diplomacy (Acheson Papers), the task of the EEC was to select the heads of missions in the associated member states, their staff and management, etc. Since 1965 (the time of establishment of the Commission of the European Communities (CES)), 21 EEC offices were opened in the associated countries to provide assistance offered under the Yaounde Conventions of 1966 - 1975 of European Development Fund. By 1973, 320 people were already working in the EEC offices. In 1972, the CES delegation became the first EU mission to the United States. The first missions, which usually carried out non-diplomatic activities, were guided by rather limited mandates and had a minimal political profile (Carta, 2012, p. 61). This experience of diplomatic activity was later used in the process of building the system of diplomatic education of the Visegrad Group states (V4).

The member states of the Visegrad Group (V4) established relations with key subjects of the world community. According to the Polish researcher K. Szczepanik, the Republic of Poland (RP) is a member of more than 40 international organizations, established cooperation with more than 190 countries, during 1995 - 2005, the number of embassies increased from 90 to 97 , consulates general - from 60 to 141, honorary consulates - from 159 to 186 , which is a total of 327 consular offices - structures operating in other countries but not in international organizations (Szczepanik, 2005, p. 225). The increase in the number of diplomatic and consular missions in the world updated the training of diplomatic personnel for them. This led to the establishment of the Diplomatic Academy at the Ministry of Foreign 
Affairs of the Republic of Poland on October 16, 2002 (Szpak, 2009, p. 135). This trend is typical of other Visegrad Group states (V4).

In general, the key goals and objectives of international policy of the Visegrad Group states (V4) coincided, they were determined by the priority areas of foreign policy, the nature of international relations between them, as well as with neighbouring European and other states, traditions of the state formation, the fact of the presence or absence of the concept of foreign policy of the state, political elite, etc. Researchers, for example, note that until 2012, Poland did not have a proper documentation of the concept of foreign policy (Priorytety, 2012). Nevertheless, the RP played a leading role in the Visegrad Group (V4). According to the Polish researcher R. Zemba, it was Poland that contributed to the development of the "new Europe" significantly, unification of Europe. Poland pointed the way to liberation from the communist regime, deprivation of the Russian presence, declared changes in democratic power, the priority of democratic values, paved the way for these changes in the East, etc. (Zieba, 2015). These and other areas became a priority in the training of diplomatic staff (Meshalskyi, 2013, pp. 47-51).

An important prerequisite for the formation and development of the system of training of diplomatic personnel of the Visegrad Group states (V4) was the creation of a regulatory framework based on relevant international and national acts. During the period under study, its formation developed in line with the Europeanization of higher education, including diplomatic, which as a result of fundamental ideological, structural changes soon highlighted the need for approval and participation in the Bologna Process, in particular the academic mobility of students. This was the focus of the Maastricht Agreement adopted on February 7, 1992 (P. 8, Art. 126), which provided for the possibility of free movement of teachers and students in the European educational space; substantiated the terms of study; aimed at learning the languages of the countries-participants, establishing close ties regarding the exchange of experience; obtaining information on the development of education in the EU member states; determined the procedure for a mutual recognition of diplomas, etc. (Treaty, 1992).

Implementation of the standards of the Bologna system was facilitated by the hard legislative activity of the Visegrad Group leadership (V4). For example, in 2002 in the Slovak Republic a number of documents regulating the development of education were adopted (Law “On Higher Schools”(№ 131/2002) (Zakon, 2002), Resolution of the Ministry of Education of the Slovak Republic "On the Credit System of Education" (Vyhlaska, 2002), Law "On the State Language of the Slovak Republic" (Zakon, 1995), Law "On Languages of National Minorities" (Zakon, 1999), two basic conceptual documents - the Concept of further development of higher education in Slovakia in the XXIst century (2000 p.) (Uznesenie, 2000) and "Millennium..." National Education Programme in the Slovak Republic for the next 15-20 years (Koncepciarozvoja vychovy a vzdelavania v Slovenskej republike na najblizsich 15-20 rokov) (Milenium, 2002), and the others which not only outlined the strategy for the development of the national system of higher education, including diplomatic, but also Europeanized it: consolidated the functioning of three types of higher education institutions (public (verejné), state (štátne) and private (súkromné)) (Zakon, 2002, p. 1462), ensured the functioning of the higher education system in terms of integration into the European educational space, structuring the list of educational programmes, specialties, introduction of the credit system of training in the Slovak Republic during 2002 - 2003 (Resolution of the Ministry of Education of the Slovak Republic "On the Credit System of Education" (Vyhlaska, 2002), which gave European content and democratic character to the domestic system of training of diplomatic personnel, enabled students to choose training courses, to build their own educational trajectory, aimed 
at the formation of professional competencies, contributed to the development of partnerships with higher education institutions and research institutions of other countries, participation in joint international projects and programmes, etc.

Thus, in the field of diplomatic education, professing the "principle of complementarity" meant that, according to current EU documents, the content of education, the organization of the educational process, etc., was the prerogative of each state. European structures are responsible for supporting and complementing national educational initiatives to strengthen the "spirit of Europe" (Treaty, 2002), in particular to improve the quality of education (Chapter 3, Article 149) through the development of the European dimension in education, through the teaching of foreign languages, starting from the lower grades; development of open and distance learning; development of the professional training system (Chapter 3 , Article 150), development of information and experience exchange on general problems of vocational training in the EU member states, etc. (Treaty, 2002). A key stage in the development of the system of diplomatic training in the Visegrad Group states (V4) was the accession to the implementation of the proposals of the European document "Memorandum on Lifelong Learning" in 2000, which outlines the provisions of lifelong learning in all areas of education. European qualification rules for the lifelong learning of young people and adults make it possible to obtain education, retrain, to raise their professional level to all comers, to compare and recognize qualifications obtained formally and informally in the EU member states, to be mobile and flexible in an ever-changing world (Memorandum, 2000). All this accelerated the process of improving the system of training of diplomatic personnel, outlined a new concept and strategy for the development of diplomatic education - lifelong learning, which the Visegrad Group states (V4) implement at the present stage of their development successfully. In the field of public administration, in the field of education, including diplomatic, in the Visegrad Group states (V4) there are qualitative changes: transition from centralized management of education to more open decentralized forms of its manifestation (The European Dimension, 1991), profile ministries, state governments hand over the part of their powers and functions to local authorities, municipalities, etc. (Dzierzgowska, 2001).

Meso-factors in the form of state policy of the Visegrad Group states (V4), the socioeconomic situation of the Eastern European region determined the external influences, the general background, the nature of relations and dictated the next challenges for the formation of diplomatic services. This was manifested in the state regulatory framework, the nature of interethnic relations, the macroeconomic situation, other social conditions and challenges that determined the content and priorities of the training system. As this issue is well covered in the scientific literature (Lukianova, 2017; Moroz, 2005; Eshtvanikova, 2004; Skrzydło, 2007; Stemplowski, 2007), we will dwell on certain aspects of this problem. These aspects include, first of all, the legislative framework for the development of the education system for the training of specialists in the field of international relations, which provided not only diplomatic missions of the states abroad, but also the highest level of public authorities, regional and local authorities, research institutions, organizations, analytical centres, etc. (Surmacz, 2015). Activities in the field of the system of diplomatic education were regulated by the "internal" legal framework. This factor needed a qualitatively new content, because all diplomatic structures of the period of "communist history" of Czechoslovakia, Poland and Hungary were dependent on the Kremlin ideologically, consistent with its policies, the Soviet ideology. All diplomatic structures became a kind of institution to support and implement the initiatives of the Soviet Union. According to the Polish researcher E. Novakowski, diplomatic 
institutions of this era had a minimum of independence, which led to the demoralization of foreign service, the inability of official authorities to form their own foreign policy concept and strategy (Novakovskyi, 2009).

According to the analysis of the source base, it should be noted that at the beginning of the 90s of the XXth century the concept of foreign policy was not developed in these countries, that is why, the development of the diplomatic service was regulated by current state documents. Relevant ministries belonged to the state structures and their activities were regulated by laws on the state authorities. On the example of the RP - this is Art. 32 of the Law "On Public Administration" (Ustawa, 1997), according to which the Foreign Minister of the Republic of Poland takes care of the relations of the Republic of Poland with other states and international structures (p. 1.1); representation and protection of Poland's interests abroad (p. 1.2); coordination of the foreign policy of the Republic of Poland (p. 1.3); representation and protection of the rights of Polish citizens and the Polish people abroad (p. 1.4); cooperation in the spheres of social development (p. 1.5); formation of the international image of Poland (p. 1.6); public and cultural diplomacy (p. 1.7), etc. (Ustawa, 1997).

Law on the Diplomatic Service of the Republic of Poland (Ustawa, 2001) was adopted only on 27 July of 2001, the RP, like other European states, in the organization of diplomatic activities was guided by a number of international instruments, including the Vienna Convention (1961), the UNO Charter (1965), Paris Charter for New Europe (1990) and the others. In addition, at the beginning of the 1990s future diplomats (based on the signing of separate documents and the introduction of a number of international programmes that were aimed at integrating higher education institutions into the world educational university space) had the opportunity to participate in European educational programmes for youth - Erasmus, LingWa, TEMPUS, Comet, Petra, Iris, Fors and the others (Meshalskyi, 2013, pp. 47-51).

As an intermediate conclusion, it should be noted that the process of establishing diplomatic services and training in international relations was complex in the Visegrad Group states (V4). However, not as critical as some researchers point out. Generalized and synthesized analysis of this work allows us to state that it is the educational traditions of the Soviet period in the form of educational institutions, which trained diplomatic personnel and were located not only in Poland, Czechoslovakia, Hungary, but also in the Soviet Union, including Ukraine, and became a factor that ensured the creation and development of diplomatic services independent of the communist regime of young European states, which had both positive and negative impact on this process. Thus, during $1944-1990$ at Taras Shevchenko University of Kyiv there were trained about 3,5 thousand international specialists, a significant part of whom were foreigners (Huberskyi, Baranov, \& Borynets, 2006, pp. 21-22). To train foreign citizens in October of 1960, the first faculty in the USSR was opened at the University, which was located in a new building equipped with modern material and technical base. During the functioning the faculty for foreign citizens, which became the part of the Ukrainian Institute of International Relations, it trained about 15 thousand students from more than 100 countries, including the states from Central and Eastern Europe (Huberskyi, Baranov, \& Borynets, 2006, pp. 15-18), such as Vasyl Hrivna the Ambassador of the Slovak Republic, Ferenc Kontra - the Ambassador of the Republic of Hungary and many others (Instytut, 2019).

Micro-factors outline the interrelated educational environment, mechanisms, means of training diplomatic staff, higher education system, retraining and professional development of specialists in international relations. In the system of diplomatic personnel training the feature 
of changes was a radical change in foreign language education of the Visegrad Group member states (V4). After the end of World War II (during 1945 - 1989) the main (first) compulsory foreign language for study was exclusively Russian at all educational levels (it has been studied since the 2 nd grade, other languages - from the 4th or 5th grade), since 1960, one of the modern foreign languages, German, English, French, and Spanish, had been introduced into the curricula of the last two years of primary school Thus, the Russian language was dominant, and the role and place of other modern languages in the curricula of primary and secondary education in this "communist region" were secondary (Ernestova, 2007).

After the fall of the Berlin Wall in the Visegrad Group states (V4) other European languages began to be studied actively, there were classes with in-depth study of foreign languages. There was a problem of training / retraining of foreign language teachers, which was resolved, inter alia, by inviting foreign representatives from the British Peace Corps, the French Alliance, the Spanish Embassy, and the others to teach, the use of educational programmes of the British Council, the Goethe Institute, etc., which affected the system of training of diplomatic personnel, led to the changes in the language repertoire of future diplomats. The establishment of the Center for Modern European Languages in Graz in 1994 and other events gave impact to active changes in the education of the Visegrad Group states (V4), transformation processes at all levels of foreign language education, including the involvement of the Czech Republic and Hungary into the EU pilot project on the implementation of the European Language Portfolio, etc. Globalization educational processes led to variability, personality-oriented and competency-based approaches to the formation of a diplomat, development of new educational standards, improvement of professional training and retraining of diplomatic personnel, in particular in the field of their language training.

Since the reform of education, culture, science was not a priority at the beginning of the 90's of the XXth century, it hindered the process of forming diplomatic systems and training diplomatic personnel (Cerych, 1997). Each of the Visegrad Group states (V4) had common formation and development features of the training system of diplomatic personnel, as well as its own trends characteristic of this process. Such a difficult way was taken by the Czech Republic and the Slovak Republic, which, most of all the Visegrad Group states (V4), were in dire need of a national diplomatic system formation. Despite somewhat different socio-political, socioeconomic, cultural and educational conditions, which determined the training of diplomatic personnel, each of the countries created a special department of administration (MFA), which organized relations with the international environment, developed high requirements for the professional profile of a diplomat. These and other principles of training diplomatic staff are clearly written in the legislation of these countries (Sprava, 1994; Statut, 1993).

Thus, since 1993, the creation of a national higher diplomatic education and the real formation of the state structures in response to the challenge posed by the newly created state began in the Slovak Republic (Statut, 1993). In a very short time, a system of the state apparatus was established, based on the ideas of parliamentary democracy, openness, and publicity. The Ministry of Foreign Affairs of the Slovak Republic was not created from scratch, the experience and resources of the Federal Ministry of Foreign Affairs and the Ministry of Foreign Relations of the Slovak Republic were used. The experience of public administration in the Czechoslovak Federation was used as well. The classic Western European model the diplomatic service was the key one. Despite the fact that during the 90 s of the XXth century the SR experienced serious staff problems, recently current staff policy has stabilized owing to the creation of its own system of training professional diplomats. However, the drawback 
is the lack of staff in the Slovak Republic, not a very wide network of missions and the number of diplomats abroad (Eshtvanikova, 2004).

The SR was able to develop its own strategy for the development of education, which came a long way: from Madarization-Sovietization to the return to national principles and nowadays the education strategy corresponds to the European level (Radek, 2008). According to the data of the researcher of development of higher education in SR M. Radek (Radek, 2008 , p. 14), the education system developed upwards, quite dynamically. For example, in 1993 there were 67,194 students of higher education institutions in the Slovak Republic, in 9 years the number of students almost doubled: 2002 - 136922 people, which, among other things, testifies to the desire of the Slovaks to improve their educational level, the dynamism of the development of higher education institutions, including diplomatic, modernization of the educational system and more. According to the Bologna Declaration (1999) (Sprievodca, 2006; TheBolognaDeclaration, 1999), in all Visegrad Group states (V4) in the system of diplomatic education introduced a two-cycle (Bachelor's and Master's) levels of training of future diplomats, the credit system (ECTS), monitored the quality of educational services (common criteria for assessing the quality of education), developed academic mobility in order to implement integrated training programmes, implementation of scientific research, created conditions for employment of graduates of the faculties of international relations and other faculties that trained diplomatic personnel in the EU countries, etc.

The strategy for the development of foreign language education adopted in the Visegrad Group states (V4) became one of the leading factors in reforming education, improving the quality of diplomatic training in the PR, the Czech Republic, the Slovak Republic and Hungary, and the successful operation of diplomatic services. Using the example of Hungary as one of the most successful countries in the development of foreign language education, we will briefly illustrate briefly how effective were European strategies for modernizing education, Pan-European recommendations on language education for the system of diplomatic training, updating the content and forms of education. According to the researchers J. Kuti and E. Morvai, in Hungary during its stay in a socialist camp, a foreign language education declined, as evidenced by the Census of 2001 (Kuti, \& Morvai, 2002). 2001 should be considered a turning point in the improvement of a foreign language education in the Visegrad Group states (V4), according to the decision of the European institutions (UNESCO, the Committee of Ministers of the Council of Europe and the European Commission) it was declared the European Year of Languages. In this regard, in 2003, Hungary adopted and launched a strategy for the modernization of a foreign language education, which is designed for the future (Language Education, 2002; Language planning, 2005). Such a state strategy gave impetus to the rapid reform of education, including the system of training diplomatic staff. Thus, according to the Census of 2001 in Hungary, during ten years of Hungarian independence (from 1990 to 2000) the number of people who studied modern European languages doubled (Kuti, \& Morvai, 2002). The strategy for the development of foreign language education in Hungary was enshrined in the National Curriculum of the Ministry of Education in 2003 (NationalCoreCurriculum, 2007), where the key objective was the formation of foreign language communicative competence of the individual, raising the foreign language education of Hungary to the level of developed European countries in the shortest possible time. This affected the quality of the future diplomat training of the new generation positively, especially the polyglot specialist.

The Conclusions. The state-building processes and qualitative changes in the geopolitical situation of the Visegrad Group states (V4) led to complex processes of creation and development 
of their own national diplomatic services, which in turn highlighted the need to provide them with qualified personnel. The creation of national systems for the training of diplomatic personnel in the Visegrad Group states (V4) is a complex and at the same time dynamic process, which has more than a quarter of a century history, marked by stages of evolutionary change that continue to this day. Three levels of determinants of the process of training diplomatic staff in the Visegrad Group states (V4) of the study period are identified. They are characterized by a number of stable and changing macro-, meso- and micro-factors, which together reflect the diversity of foreign policy, socio-political, socio-economic, cultural and educational life and emphasize the impact of these spheres of public life on the development and modernization of the system of training of diplomatic personnel in the Visegrad Group states (V4), the formation of diplomatic systems, which continue to this day. This experience is a good guide for Ukraine, which is also taking steps towards integration into the European educational space.

Acknowledgement. We express sincere gratitude to all the members of the editorial board for the advice they provided during the preparation of the article for publishing.

Financing. The authors did not receive any financial support for the research, authorship and / or publication of this article.

\section{BIBLIOGRAPHY}

Acheson Papers. (1952). Acheson Papers - Secretary of State File. URL: http://www.trumanlibrary. org/whistlestop/study_collections/achesonmemos/view.php?documentid=71-4_14\&documentYear=19 52\&documentVersion=both. [in English]

Bogaj, A. (1997). Realia I perspektywy reform oswiatowych [Reality and Perspectives of Educational Reforms]. Warszawa: Instytut Badan Edukacyjnych. 118 p. [in Polish]

Carta, C. (2012). The European Union Diplomatic Service: Ideas, Preferences and Identities. London: Routledge, 240p. [in English]

Cerych, L. (1997). Educational Reforms in Central and Eastern Europe: Processes and Outcomes. European Journal of Education, 32(1), 75-96. [in English]

Declaration on Cooperation. (1991). Declarationon Cooperation between the Czech and Slovak Federal Republic, the Republic of Poland and the Republic of Hungary in Striving for European Integration. (15.02.1991). URL: www.visegradgroup.eu/documents/visegrad-declarations. [in English]

Dzierzgowska, I. (2001). Edukacja 1997 - 2001. Raport [Education 1997 - 2001. Report]. Warszawa, 19 p. [in Polish]

Edukacja. (1998). Edukacja mlodego pokolenia Polakow I ukraincow w kontekscie integracji europejskiej: nadziejeizagrożenia [Education of the Young Generation of the Poles and Ukrainians in the Context of European Integration: Hopes and Threats]. Pod. red. Ryszard Kucha and Eugeniusz Klos. Lublin: Wydaw. UniwersytetuMarii Curie - Skłodowskiej, 483 p. [in Polish]

Ernestova, M. (2007). Teaching and learning English under the Communist Region: A Personal Account. Intercultural Communication and Foreign Language Teaching: Perspectives a Czech-German Viewpoint. Universität Augsburg, 13-20. DOI: http://10.15.507. 1991.9468.088.021.201703.371-384. [in English]

Eshtvanikova, M. (2004). Integratsiya Slovakii I Chehii v Evropeyskiy Soyuz [Integration of Slovakia and the Czech Republic into the European Union]. URL: http://www.observer.materik.ru/ observer/N10_2003/10_06.HTM [in Russian]

Hotkova, E. S. (2012). Vyishegradskaya gruppa: opyit I perspektivyi [Visegrad Group: Experience and Prospects]. Problemy Inatsionalnoy strategii-Problems of National Strategy, 4, 56-70. [in Russian]

Huberskyi, L. V., Baranov, S. I. \& Borynets, S. Ya. (2006). Instytut mizhnarodnych vidnosyn [Institute of International Relations]. Kyiv: Balance Club, 400 p. [in Ukrainian]

Instytut. (2019). Instytut mizhnarodnych vidnosyn Kyivskyi natsionalnyi universytet imeni Tarasa Shevchenka [Institute of International Relations Taras Shevchenko National University of Kyiv]. URL: http://www.iir.edu.ua/institute/history/ [in Ukrainian] 
Kish, E. V. (2012). "Evropeiska karta" krain Vyshehradskoi chetvirky: istoriia rozvytku I formy spivrobitnytstva [European Map of the Visegrad Countries: History of Development and Forms of Cooperation]. Naukovyi visnyk Mykolaivskoho natsionalnoho universytetu imeni V. O. Sukhomlynskoho. Seriia "Istorychni nauky" - Scientific Bulletin of Sukhomlynskyi Mykolaiv National University. Historical Sciences, 3(33), 259-267. URL: http://mdu.edu.ua/wp-content/uploads/2015/03/36.pdf. [in Ukrainian]

Kuti, Zs. \& Morvai, E. (2000). Concealable Framework for the Foreign language competence development programmer years 1-12. Budapest: Education Alkotoszerkeszto, 22 p. [in English]

Language Education. (2002). Language Education Policy Profile. Hungary - Strasbourg: Language Policy Division, 41 p. [in English]

Language planning. (2005). Language Planning and Policy in Europe.Vol. 2. The Czech Republic, the European Union and Northern Ireland. Ed. R. B. Bulclauf, R. B. Kaplan. Clevedon, Buffalo, Toronto: Multilingual Matters, 320 p. [in English]

Lukianova, L. (2017). Zakonodavche zabezpechennia osvity doroslykh: zarubizhnyidosvid [Legislative Support of Adult Education: Foreign Experience]. Kyiv: DKS-Centre, 147 p. [in Ukrainian]

Memorandum. (2000). Memorandum obobuchenii v techenievseyzhizni [Lifelong Education Memorandum]. URL: http://efakaz.kz/wp-content/uploads/2014/06/Memorandum-RU-LLL.pdf [in Russian]

Meshalskyi, S. (2013). Zminy polskoi systemy osvity ta ideia demokratyzatsii [Changes in the Polish Education System and the Idea of Democratization]. Osvitni reformy: misiia, diisnist, refleksiiaEducational reforms: mission, reality, reflection. Ed. V. Kremen, T. Levovatskyi, V. Ohneviuk, S. Sysoieva (Red.), (pp. 42-60). Kyiv: Edelveis. [in Ukrainian]

Milenium. (2002). Milenium: Narodny program vychovya vzdelavania $v$ Slovenskej republike na najblizsich 15 az 20 rokov [Millennium: National Programme of Education in the Slovak Republic for the next 15 to 20 years]. URL:https://www.nrsr.sk/dl/browser/document?documentid=163357 [in Slovak]

Moroz, D. O. (2005). Zasnuvannia mizhnarodnoho rehionalnoho obiednannia Vyshehrad: peredumovyinaslidky [Establishment of the International Regional Association Visegrad: preconditions and consequences]. Visnyk Derzhavnoi akademii kerivnykh kadriv kultury I mystetstv. Shchokvartalnyi naukovyi zhurnal - Bulletin of the State Academy of Management of Culture and Arts. Quarterly scientific journal, 4, 95-100. [in Ukrainian]

National Core Curriculum. (2007). National Core Curriculum (abridged version). Ministry of Education and Culture. Budapest: Ministry of Education and Culture. URL: http://www.nefmi.gov.hu/ english/hungarian-national-core. [in English]

Novakovskyi, Ye. (2009). Zakordonna polityka Polshchi: tsili i ochikuvannia [Poland's Foreign Policy: Goals and Expectations]. Ukrainian Journal, 11. URL: http://ukrzurnal.eu/ukr.archive. $\mathrm{html} / 765 /$ [in Ukrainian]

Priorytety. (2012). Priorytety Polskiej Polityki Zagranicznej. 2012 - 2016 [Priorities of Polish Foreign Policy. 2012 - 2016]. Warszawa, 29 p. URL: http://www.msz.gov.pl/resource/aa1c4aec-a52f45a7-96e5-06658e73bb4e:JCR [in Polish].

Pulishova, V. \& Strazhai, T. (2010). Ukraina ta Vyshehradska chetvirka na shliakhu do vzaiemovyhidnykh vidnosyn [Ukraine and the Visegrad Four on the Way to Mutually Beneficial Relations]. Bratyslava: ADIN, 166 p. [in Ukrainian]

Radek, M. (2008). Vysoke skolstvona Slovensku - realita, problema mozneriesenia [Higher Education in Slovakia - Reality, Problem and Possible Solutions]. Bratislava: EPPP, 38 p. [in Slovak]

Serhiienko, T. S. (2012). Rehionalna polityka krain vyshehradskoi hrupy ustanovlenni prykordonnoi ta mizhrehionalnoi spivpratsi z Ukrainoiu [Regional Policy of the Visegrad Group Countries in the Formation of Border and Interregional Cooperation with Ukraine]. Naukovyi visnyk Uzhhorodskoho universytetu - Scientific Bulletin of Uzhhorod University, 29, 42-48. [in Ukrainian]

Shishelina, L. N. (2014). Vyishegradskaya gruppa: etapy I stanovleniya i razvitiya [Visegrad Group: Stages of Formation and Development]. URL: http://www.perspektivy.info/rus/gos/vishegradskaja gruppa_etapy_stanovlenija_i_razvitija_2014-08-20.htm. DOI: http://dx.doi.org/10.15211/ soveurope620150926 [in Russian] 
Skrzydlo, W. (2009). Ustroj polityczny RP w swietle Konstytucji z $1997 \mathrm{r}$. [The Political System of the Republic of Poland in the Light of the Constitution of 1997]. Warszawa: Oficyna Wolters Kluwer, 256p. [in Polish]

Sprava. (1994). Spravao zahraniinejpolitike SR, Zuvodneho slova ministra zahranicnych vecí J. Moravcika v NR SR 2. februara 1994 [Report on the Foreign Policy of the Slovak Republic, from the Foreword by the Minister of Foreign Affairs J. Moravsík in the National Council of the Slovak Republic on 2 February 1994]. Dokumenty zahranicnej politiky SR. URL: https://www.mzv.sk/zahranicnapolitika/dokumenty-k-zahranicnej-politike.[in Slovak]

Sprievodca. (2006). Sprievodca bolonskym procesom. Slovenske vysoke skoly a bolonskyproces [Guide to the Bologna Process. Slovak Universities and the Bologna Process]. Bratislava: SAAIC-NK Socrates, 64p. [in Slovak]

Statut. (1993). Statut Ministerstva zahranicnychveci SR C. 16/93 zo dna 30.04.1993 [The Statute of the Ministerstva zahranicnychveci SR C. 16/93 on April 30, 1993]. URL: https://www.mzv.sk. [in Slovak]

Stelmakh, V. O. (2015). Politychna sotsializatsiia molodi krain Vyshehradskoi hrupy [Political socialization of the youth of the Visegrad Group countries]. Kyiv, 235 p. [in Ukrainian]

Stemplowski, R. (2007). O konstytucyjnym pojęciu prowadzenia polityki [About the Constitutional Notion of Conducting Politics]. Przeglad Sejmowy - Sejm Review, 4 (81), 229-254. [in Polish]

Surmacz, B. (2015). Ewolucja struktur organizacyjnych polskiej dyplomacji w zakresie promocji Polski na arenie międzynarodowej [Evolution of the Organizational Structures of Polish Diplomacy in the Field of Poland's Promoting in the International Arena].Miedzy Rosja a Niemcami. Dyplomacja srodkowo europejska $w$ XX wieku - Between Russia and Germany. Central European diplomacy in the 20th century. Vol. 2: 1945 - 2000; E. Alabrudzinska (red.), (pp. 315-344). Torun: Mado. [in Polish]

Szabo, I. (2008). Foreign Language Teaching in Primary Education in Hungary. Encuentro.Revista de investigacion e innovacionen la clase de idiomas, 17, 23-27. [in English]

Szczepanik, K. (2005). Dyplomacja Polski 1918 - 2005. Struktury organizacyjne [Polish Diplomacy 1918 - 2005. Organizational structures]. Warszawa: Askon, 244p. [in Polish]

Szpak, K. (2009). Polska infrastruktura dyplomatyczna [Polish Diplomatic Infrastructure]. Podmiotowosc geopolityczna. Studia nadpolska polityka zagraniczna - Geopolitical subjectivity. Studieson Polish Foreign Policy, (pp. 131-142). Warszawa: Kontrast [in Polish]

The Bologna Declaration. (1999). The Bologna Declaration of 19 June 1999. Joint declaration of the European Ministers of Education. URL: http://www.ond.vlaanderen.be/hogeronderwijs/bologna/ documents/MDC/BOLOGNA_DECLARATION1.PDF]. [in English]

The European Dimension. (1991).The European Dimension in Education: A Statement of UK Goverment's Policy and Report of Activities Undertaken to Implement the EC Resolution of 24 May 1988 on the European Dimension in Education. DFE. Department for Education, 1991, February. 15 p. URL: https://op.europa.eu/en/publication-detail/-/publication/e996e8e5-ed3e-482d-9a3c7b7eb7a19b1e/language-en [in English]

The Visegrad Group. (1993). The Visegrad Group: the Czech Republic, Hungary, Poland. URL: http://www.visegradgroup.eu/ [in English]

Treaty. (2002). Treaty establishing the European Community (Articles 149 to 150). URL: http://europa.eu.int/eur-lex/lex/en/treaties [in English]

Treaty. (1992). Treaty on European Union. URL: https://europa.eu/european-union/sites/europaeu/ files/docs/body/treaty_on_european_union_en.pdf [In English]

Ukraine. (2010). Ukraine and the Visegrad Fouron the way to mutually beneficial relations. Kyiv-Bratislava: ADIN, 166 p. [in Ukrainian]

Ustawa. (1997).Ustawa z dnia 4 wrzesnia 1997 r. o działach administracji rządowej [Act of September 4, 1997 on government administration departments. Dziennik Ustaw Rzeczypospolitej Polskiej - Journal of Laws of the Republic of Poland, 141. URL: https:// dsc.kprm.gov.pl/sites/default/ files/ustawa_z_dnia_4_wrzesnia_1997_r._o_dzialach_administracji_rzadowej.pdf [in Polish]

Ustawa. (2001). Ustawaz dnia 27 lipca 2001 r.o stużbie zagranicznej [Act of 27 July 2001 on foreign service]. Dziennik Ustaw Rzeczypospolitej Polskiej - Journal of Laws of the Republic of Poland, 128. URL: https://www.msz.gov.pl/pl/ministerstwo/sluzba_zagraniczna/ustawa_o_sluzbie_zagranicznej/ [in Polish] 
Uznesenie. (2000). Uznesenie vlady SR 685/2000 z 30. augusta 2000 k navrhu koncepcie dalsieho rozvoja vysokeho skolstvana Slovensk upre 21. Storocie [Government Resolution 685/2000 of 30 August 2000 on the proposal of the concept of further development of higher education in Slovakia for the 21st Century]. URL: http://www.vlada.gov.sk/uznesenia/2000/0830/u0685_2000.html] [in Slovak]

Visegrad Group. (2004). Visegrad Group - Your Partner. Prague: PP Agency, 197 p. [in English]

Vyhlaska. (2002).Vyhlaska Ministerstva skolstva Slovenskej republikyc. 614/2002 Z.z.z. 27. septembra 2002 okreditovom systeme studia [Decree of the Ministry of Education of the Slovak Republic no. 614/2002 Coll. Z. September 27, 2002 on the study credit system].(2002). Zbierka zakonov - Collection of Laws,239,6250-6264. [in Slovak]

Zakon. (1995). Zakonc. 270/1995 o statnom jazyku Slovenskej republiky [Act no. 270/1995 on the state language of the Slovak Republic]. URL:http://www.zakonypreludi.sk/zz/1995-270.[in Slovak]

Zakon. (1999). Zakonc.184/1999 o pouzivani jazykov narodnostnych mensin) [Act No. 184/1999 on the Use of Languages of National Minorities]. URL:http://www.zakonypreludi.sk/zz/1999-184. [in Slovak]

Zakon. (2002). Zakonc. 131/2002 Z.z. z 21. februara 2002 o vysokych skolach a o zmene a doplneni niektorych zakonov [Act no. 131/2002 Coll. of 21 February 2002 on Higher Education Institutions and on Amendments to Certain Acts]. Zbierkazakonov - Collection of Laws, 58, 1462-1514. [in Slovak]

Zieba, R. (2015). Implikacje stosunków polsko-amerykanskich dla polityki zagranicznej Polski [The Implications of Polish-American Relations for Poland's Foreign Policy]. Przeglad Politologiczny - Political Review, 2. URL: http://przeglad.amu.edu.pl/wp-content/uploads/2015/07/ pp2015-2-007.pdf [in Polish]

The article was received June 13, 2020. Article recommended for publishing 19/05/2021. 